\title{
ANALISIS FISIK PENGGUNAAN JALUR PEDESTRIAN SEBAGAI FASILIAS PUBLIK STUDI KASUS: JALUR PEDESTRIAN DI PENGGAL JALAN PENGERAN DIPONEGORO, KENARI, SENEN, JAKARTA PUSAT
}

\author{
Malik Al Karim \\ Magister Kajian Pengembangan Perkotaan, Universitas Indonesia. \\ Penulis Korespondensi e-mail: alkarimmalik@gmail.com
}

\begin{abstract}
This paper aims to look at the conditions of use of the pedestrian ways of the Diponegoro road, Central Jakarta, which has various physical characteristics,from good pedestrian ways, narrow pedestrian ways and poor pedestrian ways conditions. Basically, pedestrian ways must be accessible safely by everyone including people with disabilities. This study uses a qualitative approach. The results of this study are only fragments of the road ahead of the Pangeran Diponegoro in front of RSCM which can be accessed by everyone safely, while the pedestrian ways on the other side still has many obstacles, starting from the physical condition of the damaged and use of pedestrian ways by motorbikes that cross the pedestrian ways.

Key Words : pedestrian ways, safety, access.

ABSTRAK

Makalah ini bertujuan untuk melihat kondisi penggunaan jalur pedestrian penggal jalan Diponegoro, Jakarta Pusat yang mempunyai berbagai macam karakteristik, mulai dari jalur pedestrian yang sudah dilakukan pelebaran, jalur pedestrian yang sempit, dan jalur pedestrian yang banyak mengalami kerusakan kondisi fisik. Pada dasarnya jalur pedestrian harus bisa diakses secara aman oleh semua orang termasuk penyandang disabilitas. Penelitian ini menggunakan pendekatan kualitatif. Hasil dari penelitian ini adalah hanya penggal jalan Pengeran Diponegoro depan RSCM yang bisa diakses oleh semua orang secara aman, Sedangkan jalur pedestrian disisi lainnya masih banyak hambatan, mulai dari kondisi fisik jalur pedestrian yang rusak sampai penggunaan jalur pedestrian oleh pengendara motor yang melintas pada jalur pedestrian Kata Kunci : jalur pedestrian, keamanan, akses.
\end{abstract}


Jurnal Planologi Vol. 16, No. 1, April 2019

Available : http://jurnal.unissula.ac.id/index.php/psa

\section{PENDAHULUAN}

Saat ini, Kota Jakarta menduduki peringkat 2 untuk tingkat kemacetan di level asia dibawah Kota Bangkok, Thailand (INRIX,2016). Kemacetan di Indonesia sering terjadi pada jam sibuk masyarakat berangkat dan pulang kerja. Banyak pengguna jalan terutama motor menggunakan badan jalan atau jalur pedestrian untuk mengatasi kemacetan agar bisa mendahului kendaraan didepannya. Disisi lain, jalur pedestrian merupakan hak penuh bagi pejalan kaki yang sudah dilindungi oleh UU No. 2 Tahun 2009 tentang Lalu Lintas dan Angkutan Jalan, di pasal 13, (1) Pejalan Kaki berhak atas ketersediaan fasilitas pendukung yang berupa trotoar, tempat penyeberangan, dan fasilitas lain, dan (2) Pejalan Kaki berhak mendapatkan prioritas pada saat menyeberang Jalan di tempat penyeberangan.

Berdasarkan data World Health Organization (WHO), pada tahun 2010 di seluruh dunia, 22\% korban kecelakaan adalah pejalan kaki dibawah pengguna mobil $31 \%$ dan kendaraan roda 2-3 23\%. Artinya angka tersebut masih sangat tinggi dan negara penyumbang kecelakaan pengguna pejalan kaki mayoritas dari negara berpenghasilan rendah dan menengah (WHO, 2013). Sementara itu, Direktur Keselamatan Transportasi Darat Ditjen Perhubungan Darat Kementerian Perhubungan mengatakan pada tahun 2013 angka kecelakaan dengan korban pejalan kaki di Tanah Air juga menurutnya memiliki persentase yang cukup tinggi yakni sekitar 30\% dari 3.675 kasus kecelakaan yang terjadi sepanjang 2013 (Industri.bisnis.com, 2014, diakses Januari 2018).

Le Corbusier (1929, dalam LeGates and Stout, 2016) mengatakan bahwa traffic lalu lintas yang tinggi sering membahayakan para pengguna pedestrian bahkan banyak kecelakaan (membunuh) diakibatkan para pengguna kendaraan bermotor di jalan raya. Dalam kongress New Urbanism pada tahun 1993 di Chicago yang menghasilkan prinsip dan guidelines dalam perencanaan dan pembangunan kota menyatakan bahwa pada suatu kota-kota metropolis kontemporer, pembangunan harus mengakomodasi mobil secara memadai. Ini harus dilakukan dengan cara yang menghormati pejalan kaki (Congress of New Urbanisme,1993 dalam LeGates and Stout, 2016:413).

Hakikatnya jalur pedestrian dibuat untuk pergerakan manusia dari satu tempat ke tempat yang lain dengan moda berjalan kaki, dan bisa diakses oleh siapapun baik bagi anak kecil, lansia, ibu hamil, mupun penyandang disabilitas. Pedestrian juga harus bisa diakses oleh semua orang dengan aman dan nyaman. Pedestrian yang merupakan satu kesatuan dengan jalan bisa dikatakan sebagai wujud citra dari kota tersebut, jika jalanan suatu kota 
Jurnal Planologi Vol. 16, No. 1, April 2019

itu indah maka kota tersebut akan indah, jika jalanan kota tersebut buruk maka wujud dari kota tersebut juga buruk (Jacob, 1961 dalam LeGates and Stout, 2016:150).

Jalan Pangeran Diponegoro di area depan Rumah Sakit Cipto Mangunkusumo merupakah salah satu penggal jalan yang dilakukan pengembangan jalur pedestrian pada tahun 2016 dengan lebar sampai 7 meter. Hal ini dilakukan Pemerintah DKI Jakarta dalam rangka memberikan akses sirkulasi yang lebih aman dan nyaman bagi pengguna jalur pejalan kaki serta merubah konsep moving rider menjadi moving people (http://www.viva.co.id, diakses 27 Januari 2018). Banyaknya pengguna pejalan kaki di penggal jalan tersebut juga dipengaruhi oleh guna lahan disekitarnya yang heterogen, mulai dari rumah sakit, perkantoran, komersil, universitas, perumahan, dan sekolah. Akan tetapi di berbagai ruas jalur pedestrian terkadang muncul sektor informal yang berjualan di pedestrian. Kendaraan bermotor juga melewati pedestrian ketika jalanan sedang macet. Pedestrian dijadikan sebagai tempat parkir motor. Jalur pedestrian sebagai elemen penting suatu kota juga sering tidak menjadi perhatian khusus bagi pemerintah kota dalam perencanaannya. Pembangunan berorientasi pada pelebaran jalan tanpa mempertimbangkan jalur pedestrian yang baik dipinggirnya. Akhirnya banyak jalur pedestrian yang dibangun tidak aman dan nyaman untuk diakses oleh masyarakat, bahkan jalur pedestrian yang ada tidak bisa diakses oleh penyandang disabilitas atau berkebutuhan khusus.

Adanya pengembangan jalur pedestrian di penggal jalan Pangeran Diponegoro merupakan salah satu langkah untuk memberikan hak bagi para pejalan kaki. Akan tetapi pengembangan jalur pedestriannya hanya sepanjang sepanjang 600 meter. (googlemaps, diakses 17 Desember 2017). Disisi lain, jalan Pangeran Diponegoro tersebut masih banyak jalur pedestrian yang sempit. Saat ini belum diketahui bagaimana penggunaan jalur pedestrian di penggal jalan Pangeran Diponegoro sepanjang 900meter baik dari sisi akses maupun keamanan dari para pengguna jalur pedestrian tersebut. Berdasarkan hal tersebut penelitian ini akan mengidentifikasi penggunaan jalur pejalan kaki di jalan Pangeran Diponegoro apakah bisa diakses dan dilalui oleh semua pelaku pejalan kaki secara aman dan nyaman.

\section{METODOLOGI PENELITIAN}

Penyusunan makalah ini menggunakan pendekatan kualitatif yaitu Pendekatan sebagai strategi penelitian yang menekankan pada interprestasi terhadap data yang ditemukan di lapangan dan mengeksplorasi temuan-temuan lapangan sebagai pola pikir 
Jurnal Planologi Vol. 16, No. 1, April 2019

dalam menganalisis dan menjawab pertanyaan penelitian (Yunus, 2010). Pendekatan kualitatif dilakukan untuk mendapatkan gambaran dari kondisi dan penggunaan pedestrian di penggal jalan Pangeran Diponegoro sehingga bisa mendapatkan informasi untuk di kaitkan dengan teori dan pendekatan mengenai penggunaan dan keamanan pengguna jalur pedestrian.

Sumber data terdiri dari sumber data primer dan sekunder. Sumber data primer dilakukan dengan pengambilan dokumentasi gambar dan pengamatan langsung di lapangan. Pengambilan dokumentasi gambar dan pengamatan berfokus pada gambaran kondisi fisik jalur pedestrian, mengidentifikasi fasilitas yang ada pada jalur pedestrian, mengidentifikasi siapa pengguna jalur pedestrian, mengidentifikasi guna lahan disepanjang jalur pedestrian dan mengidentifikasi jumlah pengguna jalur pedestrian. Sumber data sekunder diperoleh dengan pengumpulan data melalui buku, penelitian dalam bentuk laporan lembaga riset, peta googlemaps untuk gambaran lokasi penelitian dan analisis, serta berita dari sumber laman pencari data di internet.

Penelitian ini dilakukan selama 3 hari pada hari kerja (weekdays) dan akhir pekan yaitu Sabtu, Minggu, dan Senin. Lokasi penelitian ini adalah di penggal jalan Pangeran Diponegoro, Kenari, Senen, Jakarta Pusat sepanjang 900 Meter. Penggal jalan Pangeran Diponegoro ini dipilih karena mempunyai keunikan karakteristik yaitu fungsi bangunan di sekitarnya yang beragam terdiri dari perkantoran dan jasa, komersil, perumahan, rumah sakit, universitas, dan sekolah. Disisi lain, terdapat bagian penggal jalan Dipongero yang dilakukan pengembangan jalur pejalan kaki selebar 7 meter dan pembangunan taman publik di samping jalur pedestrian sehingga akan dapat melihat dari 2 kondisi jalur pedestrian, yang sudah dilakukan pengembangan dan yang belum dilakukan pengembangan. Hal ini dianggap dapat mewakili jawaban terhadap permasalahan penelitian bagaimana penggunaan jalur pedestrian dan apakah jalur pedestrian tersebut bisa diakses semua orang secara nyaman.

Dalam penelitian ini, observasi lapangan dibagi menjadi 2 bagian dikarenakan keterbatasan jarak pengamatan penulis untuk melihat karakteristik pengguna jalur pedestrian dan perhitungan jumlah pengguna jalur pedestrian tersebut. Lokasi penelitian ini bisa dilihat pada gambar di bawah ini: 


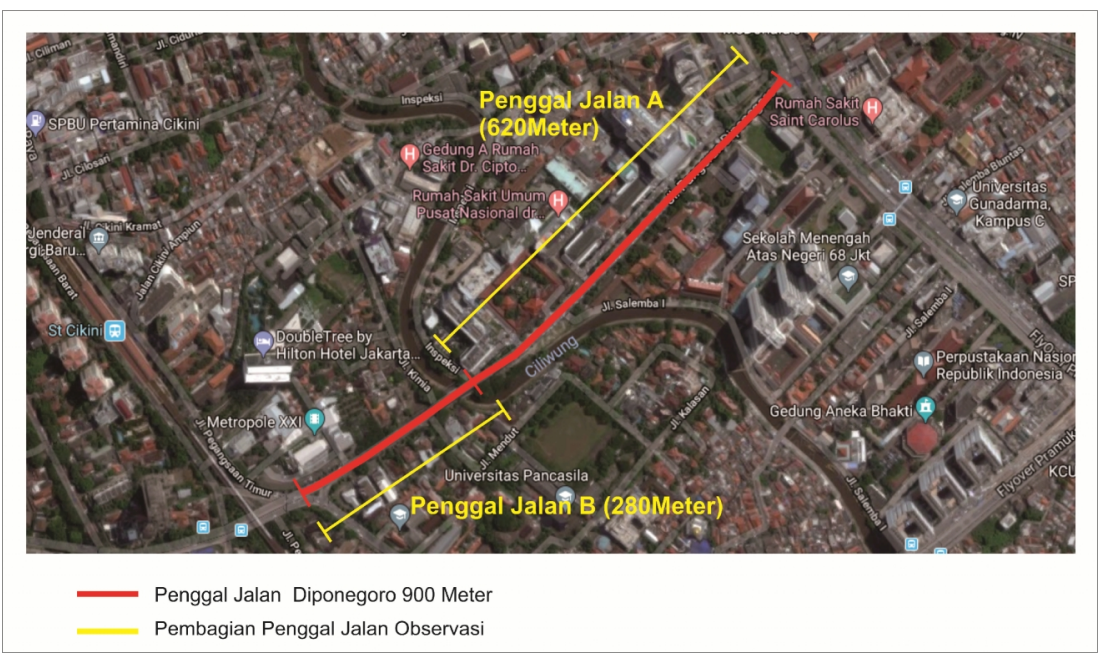

Gambar 1 Lokasi penggal Jalan Pangeran Diponegoro yang dijadikan sebagai lokasi penelitian Sumber: https://www.google.co.id/maps/@-6.1979447,106.8471998,899m/data=!3m1!1e3?hl=en diolah oleh penulis, Januari 2018

\section{Konsepsi Jalur Pejalan Kaki}

Lingkungan pejalan kaki yang ramai merupakan prasyarat untuk keamanan kota dengan mengarahkan para pengguna pedestrian sendiri yang saling mengawasi (Jacob, 1961), merekomendasikan sejumlah besar toko, bar, restoran, dan tempat umum lainnya "ditaburi di sepanjang trotoar" sebagai bentuk kontrol sesama pengguna trotar. Jika tindak kejahatan atau kriminal di jalan tinggi, maka masyarakat akan merasa takut dan bisa jadi beralih ke moda lain untuk melakukan mobilitas (Jacobs, 1961). Le Corbusier (1929, dalam LeGates and Stout, 2016) mengatakan bahwa traffic lalu lintas yang tinggi sering membahayakan para pengguna pedestrian bahkan banyak kecelakaan (membunuh) diakibatkan para pengguna kendaraan bermotor di jalan raya. Dalam kongres New Urbanism pada tahun 1993 di Chicago yang menghasilkan prinsip dan guidelines dalam perencanaan dan pembangunan kota menyatakan bahwa pada suatu kota kota metropolis kontemporer, pembangunan harus mengakomodasi mobil secara memadai. Ini harus dilakukan dengan cara yang menghormati pejalan kaki (Congress of New Urbanisme, 1993 dalam LeGates and Stout, 2016).

Lynch (1981) menyatakan bahwa akses adalah salah satu elemen pembentukan kota. Akses disini artinya tingkatan dimana kota memiliki kemudahan pelayanan yang dapat dijangkau oleh masyarakat, kemudahan melakukan aktivitas kota, kemudahan menjangkau sumber daya, kemudahan pelayanan dan pencapaian, kemudahan informasi atau kemudahan menjangkau tempat (Lynch, 1981). Kemudahan akses ini harus berlaku 
bagi semua orang termasuk orang yang memiliki kemampuan berbeda seperti anak kecil, penyandang disabilitas, orang lanjut usia, orang sakit, ibu hamil, dll. (Lynch, 1981). Lynch (1960) juga menentukan elemen pembentuk citra kota yang salah satunya adalah path. Path adalah suatu jalur yang biasanya digunakan orang untuk melakukan pergerakan secara umum. Path dapat berupa jalan raya, jalur pejalan kaki (walk ways), jalur transit, kanal, jalur kereta api dll (Lynch, 19601). Bagi kebanyakan orang path merupakan elemen yang paling penting dalam pembentukan image kota. Sama dengan apa yang diutarakan oleh Jacob (1961) bahwa jalan dan pedestriannya merupakan organ vital suatu kota dimana mencerminkan baik atau buruknya suatu kota secara visual.

\section{HASIL DAN PEMBAHASAN}

\subsection{Profil Jalur Pedestrian Penggal Jalan Pangeran Diponegoro}

Jalur pedestrian di Jalan Pangeran Diponegoro dalam penelitian ini mempunyai panjang penggal jalan sekitar 900 Meter. Secara umum gambaran pedestrian di penggal jalan bisa dilihat pada gambar dibawah ini:

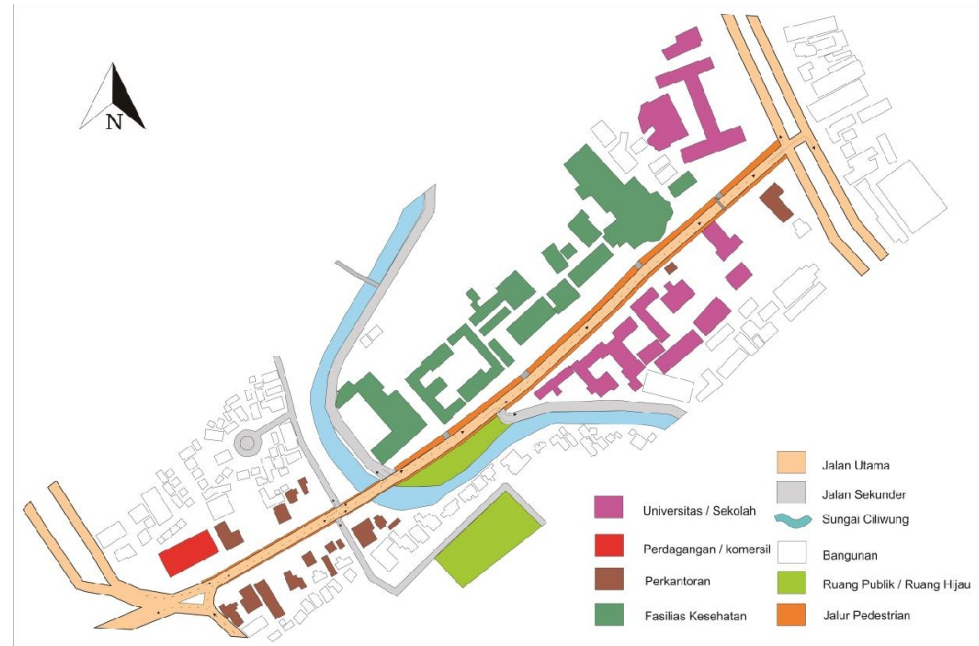

Gambar 2 Tampak atas jalur pedestrian dan fungsi bangunan di sekitar penggal Jalan Pangeran Diponegoro

Sumber: https://www.google.co.id/maps/@-6.1979447,106.8471998,899m/data=!3m1!1e3?hl=en diolah oleh penulis, Januari 2018, Observasi lapangan Januari 2018

Dari gambar 2 dapat dilihat bahwa kondisi jalur pedestrian di penggal jalan Pangeran Diponegoro mempunyai lebar jalur pedestrian yang bervariasi mulai dari 1 meter sampai 7 meter. Jalur pedestrian yang lebar terletak di sisi depan fasilitas kesehatan RSCM sampai ke Fakultas Kedokteran Universitas Indonesia. Secara fungsi bangunan kawasan sekitar penggal jalan Pangeran Diponegoro didominasi oleh perkantoran, fasilitas 
kesehatan, dan fasilitas pendidikan. Fungsi bangunan disepanjang penggal jalan Dipongero akan mempengaruhi karakteristik dan intensitas pengguna jalur pedestrian. Secara detail jalur pedestrian tersebut bisa dilihat pada gambar diberikut ini:

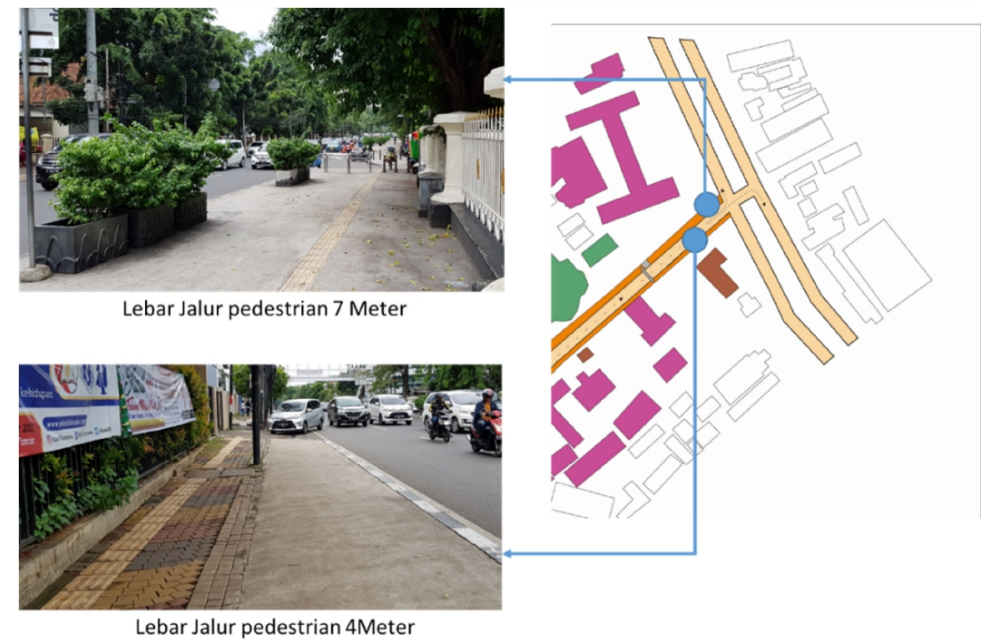

Gambar 3 Lebar jalur pedestrian di salah satu penggal jalan Pangeran Diponegoro Sumber: googlemaps, 2018. Dokumentasi penulis, Januari 2018.

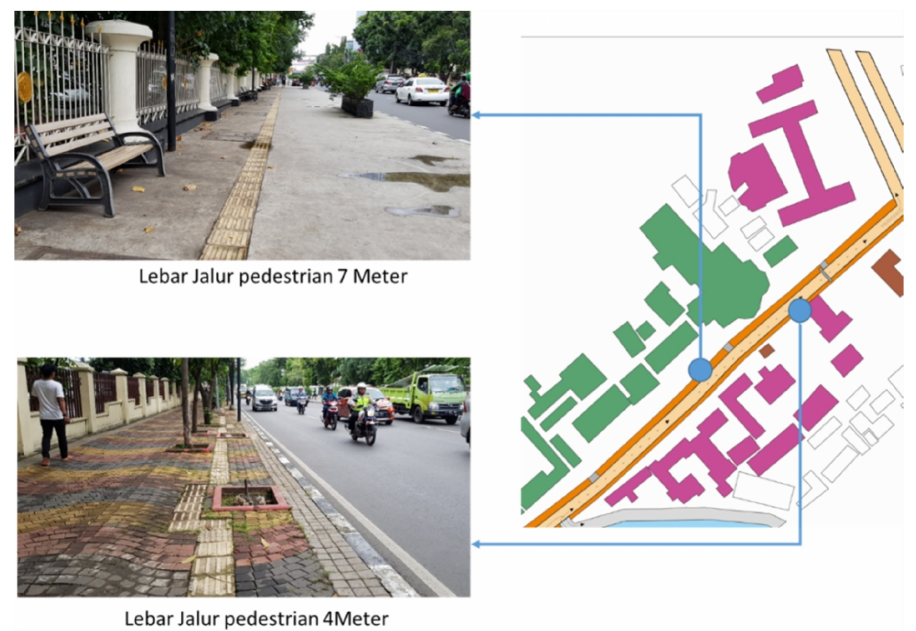

Gambar 4 Lebar jalur pedestrian di salah satu penggal jalan Pangeran Diponegoro Sumber: googlemaps, 2018. Dokumentasi penulis, Januari 2018.

Pada gambar 4. Jalur pedestrian dengan lebar 7 Meter terletak di depan RSCM. Jalur pedestrian tersebut dilengkapi dengan tempat duduk untuk para pejalan kaki yang ingin bersantai. Ketinggian jalur pedestrian ini sekitar $25 \mathrm{~cm}$. Pada jalur pedestrian ini terdapat kotak sampah yang diletakkan di pinggir pedestrian dan tanaman hijau di sisi yang berdekatan dengan jalan raya. Hal ini mungkin untuk memberikan batasan jarak antara pengguna jalur pedestrian dengan kendaraan bermotor baik mobil maupun motor. 


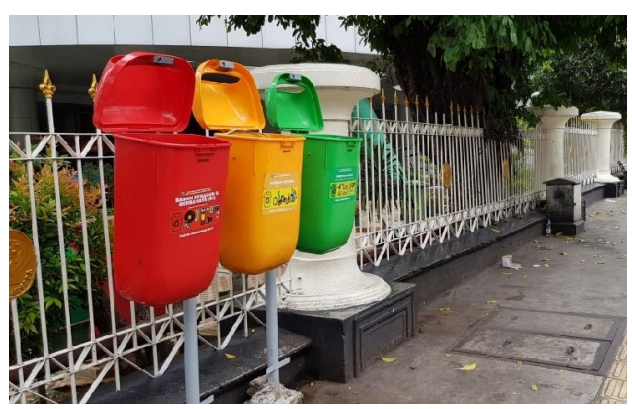

Gambar 5 Kotak sampah sebagai fasilitas jalur pedestrian

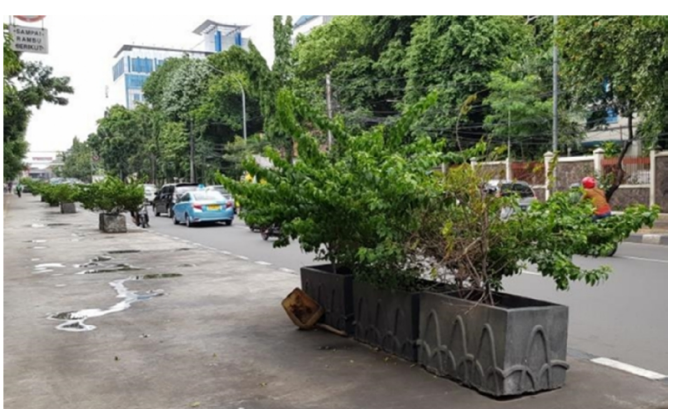

Gambar 6 Tanaman diletakkan di sisi dekat jalan

Sumber: Dokumentasi penulis, Januari 2018

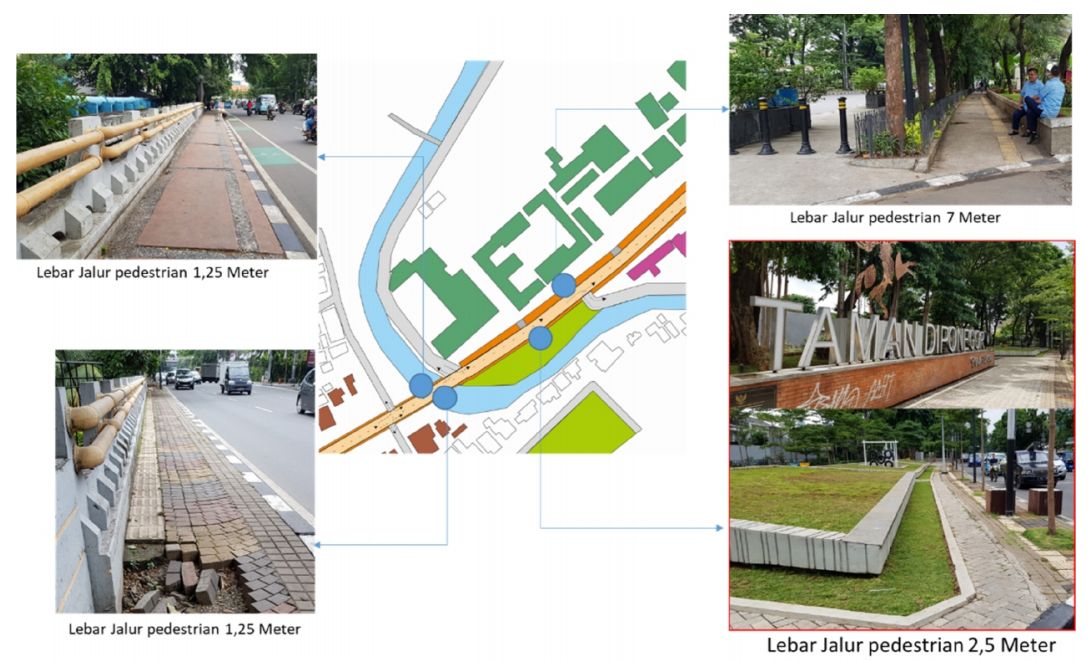

Gambar 7. Lebar jalur pedestrian di salah satu penggal jalan Pangeran Diponegoro Sumber: googlemaps, 2018. Dokumentasi penulis, Januari 2018.

Pada gambar 7. Jalur pedestrian didepan RSCM terdapat Taman Diponegoro sebagai ruang publik dan ruang hijau di area tersebut. Jalur pedestrian di Taman Diponegoro tersebut dibuat menyatu dengan taman, tapi dalam observasi lapangan, penggunaan ruang publik di Taman Diponegoro masih sangat sedikit. Jalur pedestrian pada jembatan Sungai Ciliwung dibuat menyempit dengan lebar 1,25 Meter. Terdapat beberapa bagian yang rusak di jalur pedestrian jembatan tersebut dan ada sisi jalur pedestrian yang tidak dilengkapi dengan tactile paving atau jalur khusus penyandang tunanetra. Pada sisi depan RSCM, jalur pedestrianya diberikan taman yang dipagari dibagian tengah dengan lebar jalur pedestrian 7 meter. 

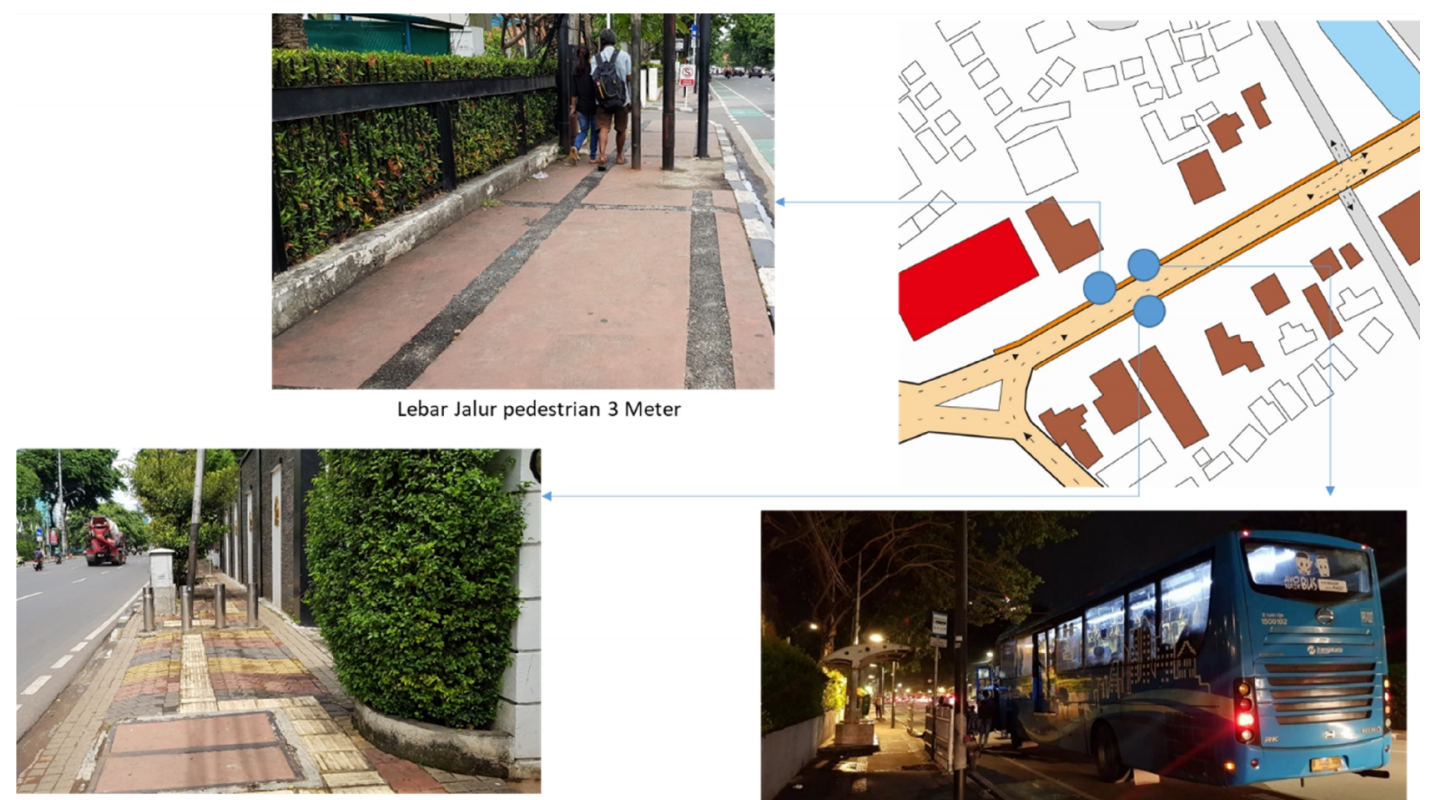

Lebar Jalur pedestrian 3 Meter

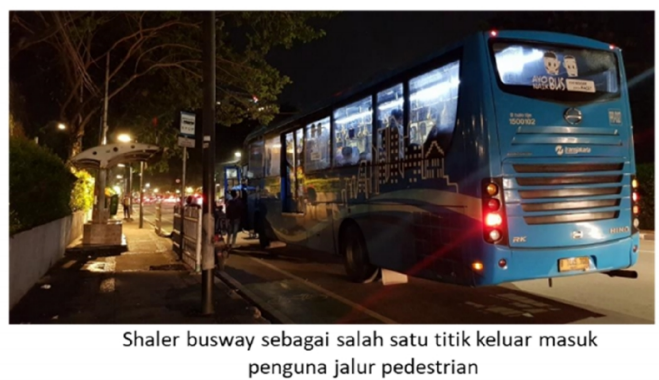

Gambar 8 Lebar jalur pedestrian di salah satu penggal jalan Pangeran Diponegoro dan shalter busway sebagai titik keluar masuk pengguna jalur pedestrian Sumber: googlemaps, 2018. Dokumentasi penulis, Januari 2018.

\subsection{Karakteristik dan intensitas pengguna jalur pedestrian}

Karakteristik pengguna jalur pedestrian jalan Pangeran Diponegoro didominasi oleh orang yang melakukan aktivitas di sepanjang fasilitas kesehatan yaitu RSCM dan Pusat Kesehatan Ibu dan Anak. Berdasarkan hasil observasi lapangan, berikut ditampilkan data secara kuantitatif penggunaan jalur pedestrian di penggal jalan Pangeran Diponegoro. Karena keterbatasan jarak pengamatan dari penulis, maka perhitungan jumlah pengguna pedestrian dibagi menjadi 2 sisi penggal jalan, penggal jalan A sepanjang 620 meter, dan penggal Jalan B sepanjang 280 Meter. 


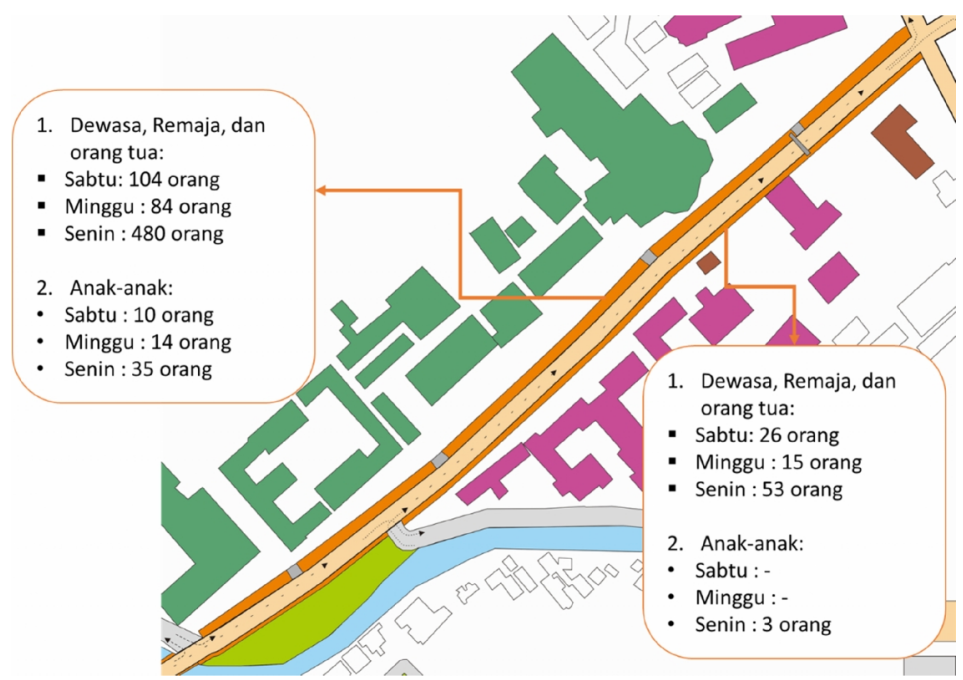

Gambar 9 Data jumlah pengguna jalur pedestrian pada penggal A jalan Pangeran Diponegoro

Sumber: googlemaps, 2018. Observasi lapangan pukul 11.00-13.00, 19,20,21 Januari 2018

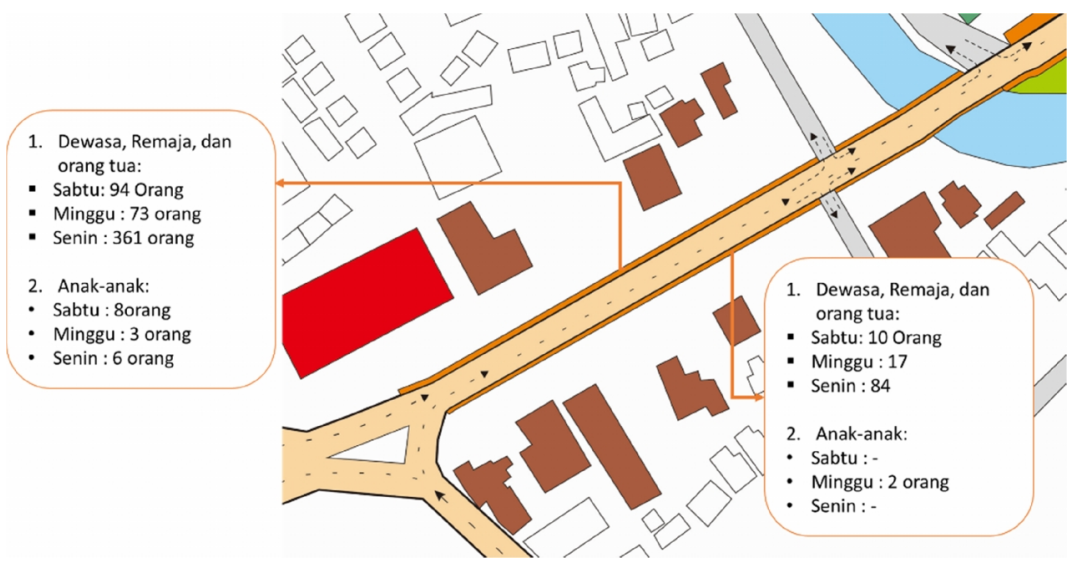

Gambar 10 Data jumlah pengguna jalur pedestrian pada penggal A jalan Pangeran Diponegoro

Sumber: googlemaps, 2018. Observasi lapangan pukul 13.00-15.00, 19,20,21 Januari 2018

Berdasarkan data diatas, penggunaan jalur pejalan kaki paling banyak paling ramai pada waktu siang hari sekitar pukul 11.00-13.00 pada hari Senin atau hari kerja yang mayoritas didominasi pengguna jalur pedestrian ini berasal dari kawasan RSCM baik yang keluar, maupun pengunjung yang datang menggunakan kendaraan mobil atau motor. Sisi jalur pedestrian di depan RSCM tidak begitu ramai termasuk pada jam sibuk seperti siang ataupun sore. Adanya halte busway juga menjadi salah satu titik masuk pengguna jalur pedestrian. Pengguna jalur pedestrian mayoritas adalah orang dewasa, remaja, beberapa orang tua dan anak-anak yang ditemani oleh orang tuanya. Penulis belum menemukan adanya pengguna berkebutuhan khusus (disabilitas) yang menggunakan jalur pedestrian. 


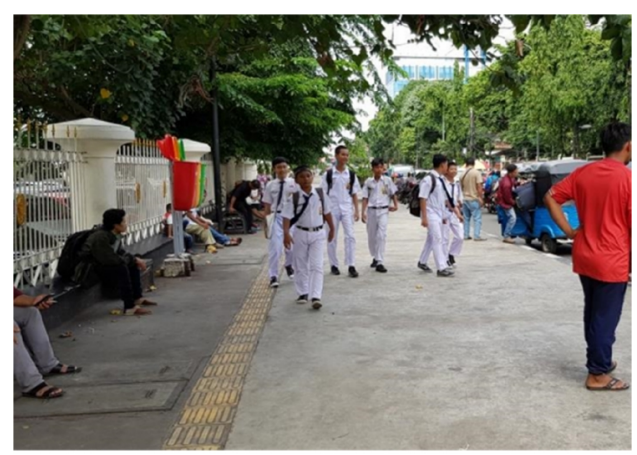

Gambar 11 Pengguna jalur pedestrian pelajar

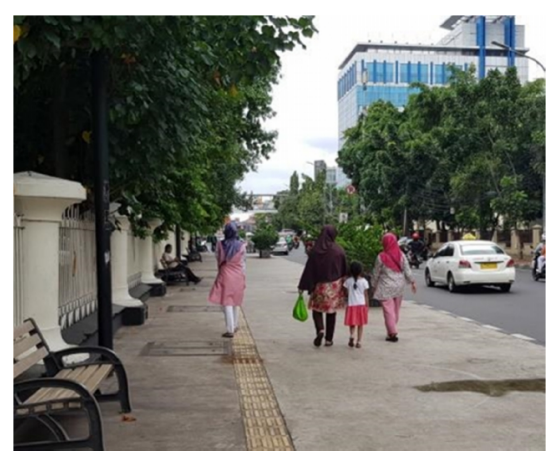

Gambar 12 Pengguna jalur anak-anak dengan orang tuanya

Sumber: Dokumentasi penulis, Januari 2018.

Pada jalur pedestrian didepan RSCM terdapat pedagang informal yang berjualan, dengan menggunakan sepeda, dengan berjalan kaki yang bisa bergerak secara cepat. Hal ini dikarenakan pedakang sektor informal tersebut tidak diizinkan berjualan di jalur pedestrian. Hal ini juga disampaikan oleh salah satu pedagang makanan bernama Ibu Ida sebagai berikut:

....kita gak boleh jualan disini mas, jadi cuma nawarin aja dijalan kayak gini, atau yang kayak pake sepeda itu, kadang petugas satpam rumah sakit juga ngusir kita kalo lagi dagang disini, Cuma kadang-kadang doank mereka ngusir kita...(Ibu Ida, Pedagang Nasi Pecel, 21 Desember 2017)

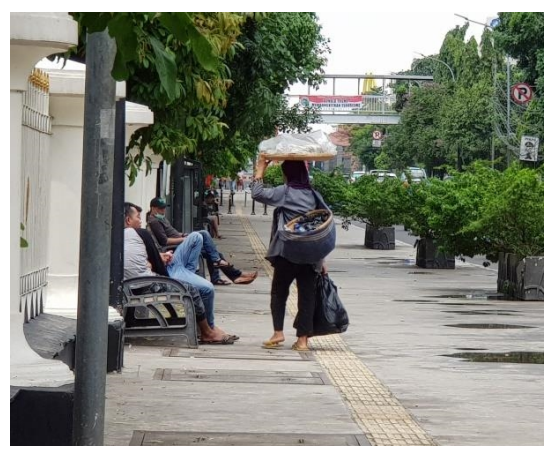

Gambar 13 Pedagang makanan keliling yang sedang berjualan

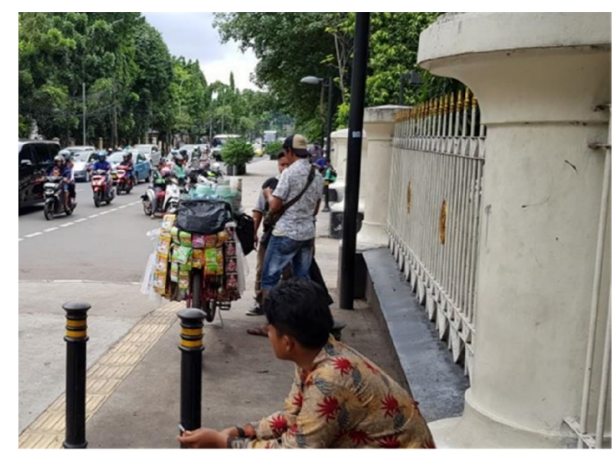

Gambar 14 Pedagang minuman bersepeda di jalur pedestrian depan RSCM.

Sumber: Dokumentasi penulis, Januari 2018.

Mereka dilarang berjualan karena tidak sesuai dengan perda no 8 Tahun 2007 yaitu dilarang berdagang, melakukan kegiatan usaha di bagian jalan /trotoar atau tempat umum. Peraturan tersebut juga dipasang pada salah satu bagian jalur pedestrian di depan RSCM. 
Jurnal Planologi Vol. 16, No. 1, April 2019

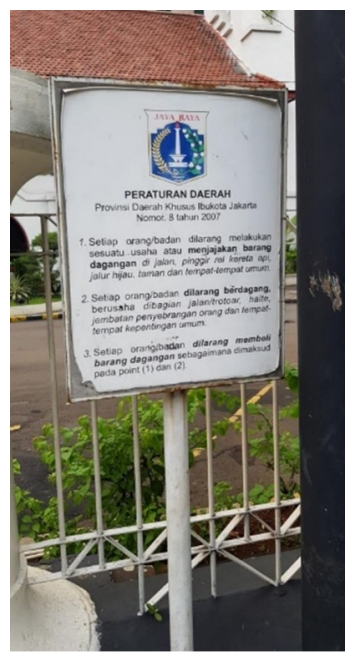

Gambar 15 Plang pemberitahuan tidak diizinkan melakukan kegiatan usaha di jalur pedestrian depan RSCM.

Sumber: Dokumentasi penulis, Januari 2018

Pada jalur pedestrian diseberang RSCM atau depan SMP K 3 Penabur, pedagang kaki lima menggelar dagangannya secara bebas baik pada siang hari maupun pada malam hari. Pedagang kaki lima tersebut berjualan makanan dan minuman dengan lapaknya sampai menutupi sebagian besar jalur pedestrian.

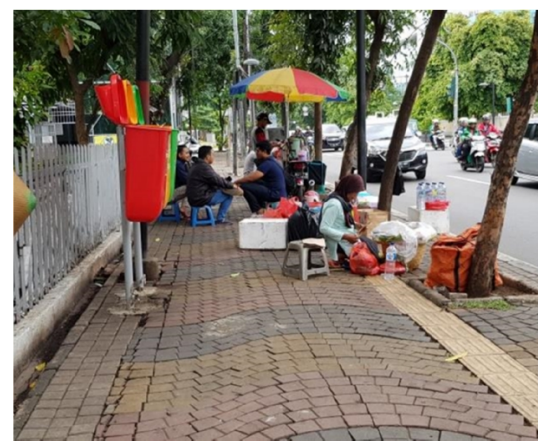

Gambar 16 Pedagang makanan yang berjualan diseberang pintu gerbang RSCM yang

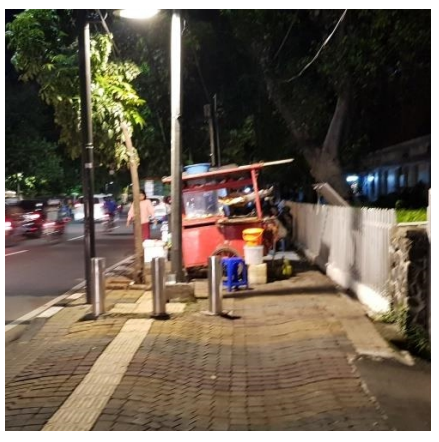

Gambar 17 Pedagang makanan yang berjualan diseberang pintu gerbang RSCM yang menggunakan jalur pedestrian pada siang hari. menggunakan jalur pedestrian pada malam hari. Sumber: Dokumentasi penulis, Januari 2018

\section{Hambatan Fisik Jalur pedestrian (aksesible)}

Berdasarkan hasil observasi lapangan di sepanjang jalur pedestrian penggal jalan Pangeran Diponegoro, akses pejalan kaki masih sering terhambat oleh beberapa faktor yaitu: 
1. Kendaraan bermotor yang melintasi jalur pedestrian.

Pengguna kendaraan bermotor masih ada beberapa yang melintasi jalur pedestrian, pengguna kendaraan bermotor ini pada umumya adalah ojek online ataupun ojek pangkalan. Pengguna motor yang melintas jalur pedestrian paling banyak pada jalur depan RSCM, mereka melintas jalur pedestrian pada umumnya untuk menunggu penumpang. Penghalang jalur pedestrian sebenarnya sudah dibuat pada jalur tersebut, akan tetapi adanya jalur untuk penyandang disabilitas lewat yang lebih lebar dijadikan tempat masuk bagi pengguna motor tersebut.
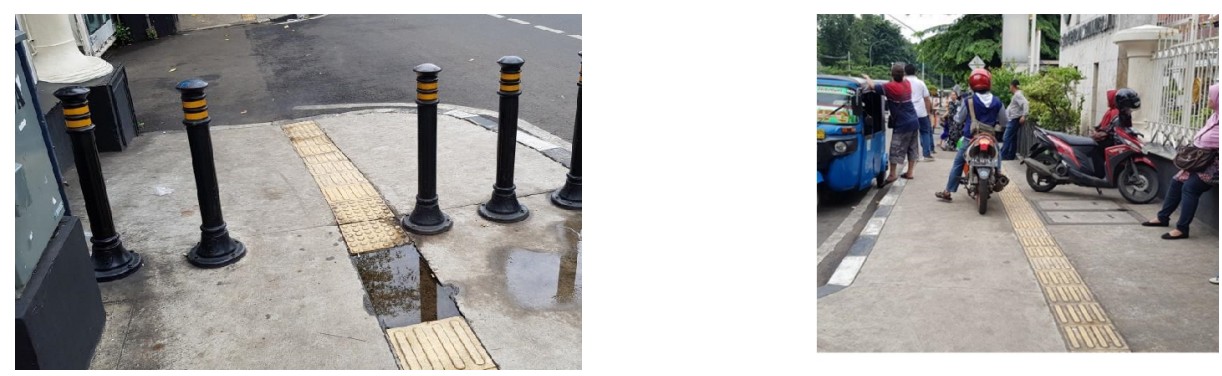

Gambar 18 penghalang jalur pedestrian, dan sisi Gambar 19 Kendaraan bermotor masuk ke jalur untuk penyandang disabilitas sebagai akses masuk kendaraan bermotor. pedestrian.

Sumber: Dokumentasi penulis, Januari 2018

Pada sisi penggal B jalur pedestrian jalan Pangeran Diponegoro tepatnya di jembatan, banyak ditemukan kendaraan bermotor yang melintas dan mengganggu para pejalan kaki. Hal ini dikarenakan dengan lebar pedestrian yang hanya 1,25 meter, ketika ada motor yang melintas di jalur pedestrian akan membuat pejalan kaki tersebut harus berenti dan berhati-hati. Kendaraan bermotor ini melintas biasanya pada saat macet.

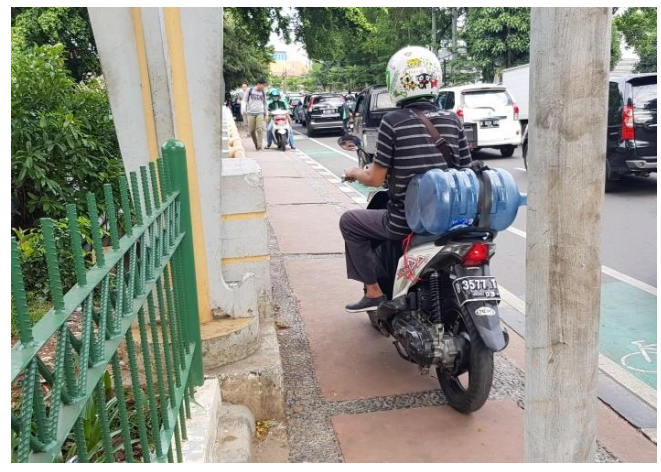

Gambar 20 Motor melintas di jalur pedestrian

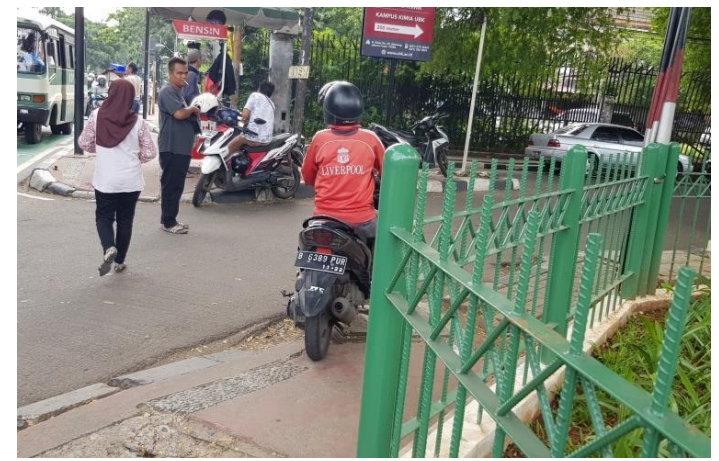

Gambar 21 motor melintas pada jalur pedestrian dan melawan arah.

Sumber: Dokumentasi penulis, Januari 2018 
2. Kondisi fisik jalur pedestrian yang banyak rusak dan banyak penghambat.

Jalur pedestrian dibuat untuk bisa diakses oleh semua orang. Pada penggal jalan Pangeran Diponegoro ini, masih banyak kondisi fisik jalur pedestrian yang tidak layak, sudah rusak, maupun penghalang dijalan seperti pohon, gardu dan tiang listrik maupun telfon serta ada beberapa bagian jalur pedestrian yang belum mempunyai jalur untuk penyandang tunanetra. Pada jalur pedestrian depan RSCM, mempunyai kualitas dan kondisi yang paling baik diantara sisi pedestrian yang lain. Hal ini dikarenakan tersedianya fasilitas yang cukup lengkap seperti jalur khusus penyandang tuna netra, adanya tempat duduk untuk bersantai ataupun interaksi sosial, dan penyebrangan bagi yang mengakomodir penyandang disabilitas.

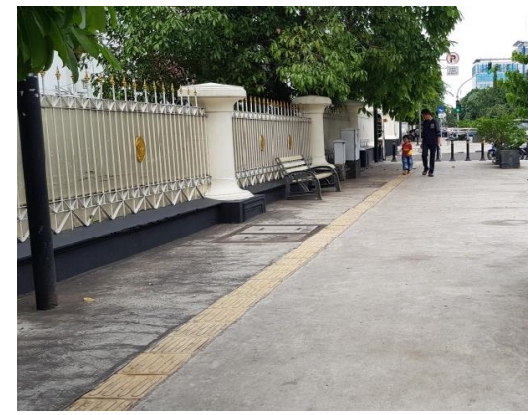

Gambar 22 Jalur khusus tunanetra

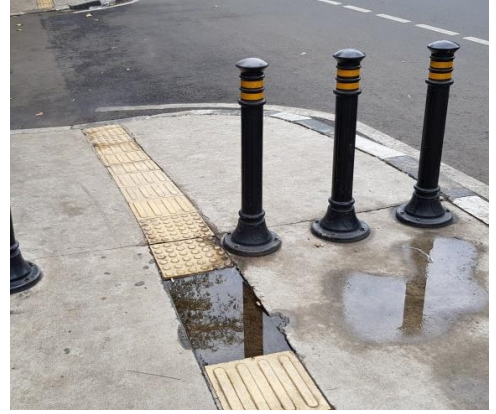

Gambar 23 jalur khusus tunanetra rusak Sumber: Dokumentasi penulis, Januari 2018

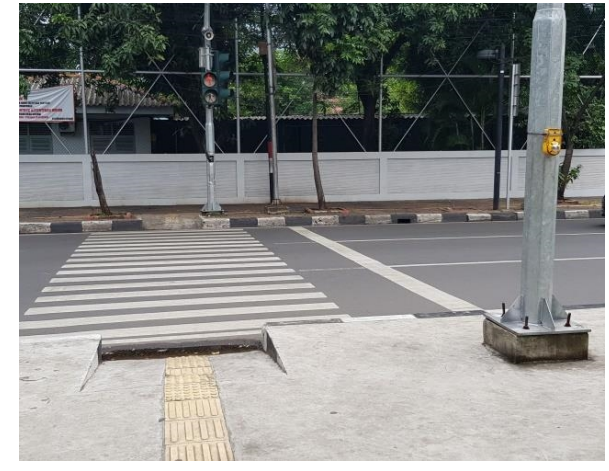

Gambar 24 fasilitas penyebrangan yang bisa dilalui oleh penyandang disabilitas

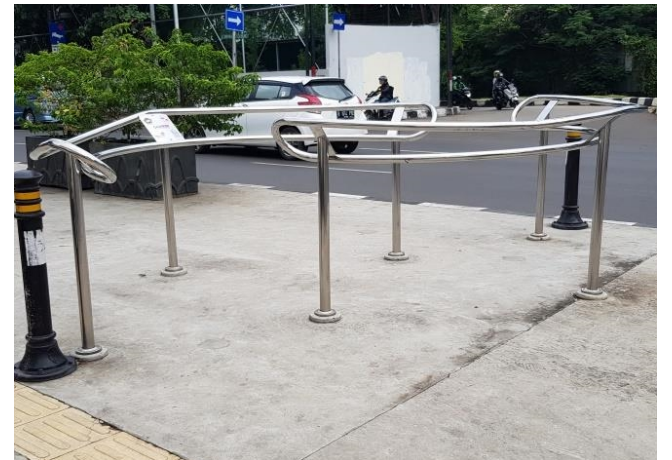

Gambar 25 fasilitas penyandang disabilitas didepan RSCM

Sumber: Dokumentasi penulis, Januari 2018

Sedangkan pada jalur pedestrian seberang RSCM mempunyai banyak hambatan yang sulit bisa diakses terutama para peyandang disabilitas. Mulai dari jalur khusus tunanetra yang tidak lurus dan terputus, serta jarak dengan dinding pagar bangunan dan sisi jalan yang tidak teratur. Disisi lain, banyaknya tiang listrik dan tiang lain yang menjadi halangan dan hambatan tidak hanya bagi penyandang disabilitas tapi juga bagi pengguna 
jalur pedestrian pada umumnya. Terdapat juga di sisi Penggal jalur pedestrian B (dekat dengan halte busway) tidak mempunyai jalur khusus tunanetra, sehingga bisa dipastikan penyandang disabilitas tidak bisa melewati jalut pedestrian tersebut. Beberapa dokumentasi dari hambatan pada jalur pedestrian Pangeran Diponegoro bisa dilihat dibawah ini:

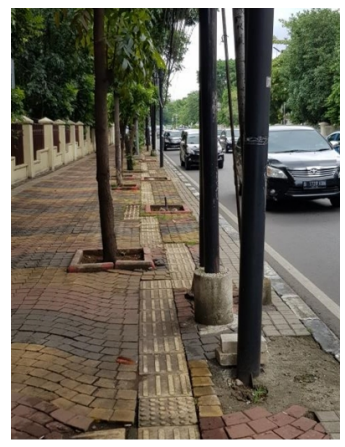

Gambar 26 Jalur khusus tunanetra yang mendekati sisi jalan

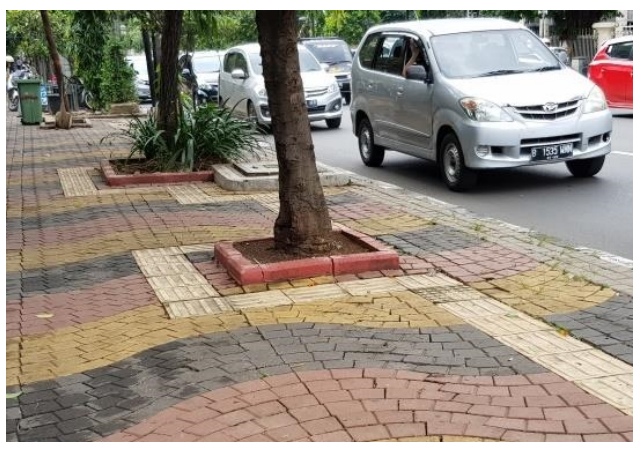

Gambar 27 alur khusus tunanetra yang tidak lurus

Sumber: Dokumentasi penulis, Januari 2018

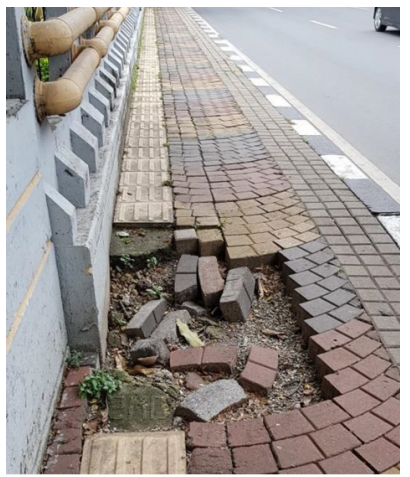

Gambar 28 Jalur pedestrian rusak

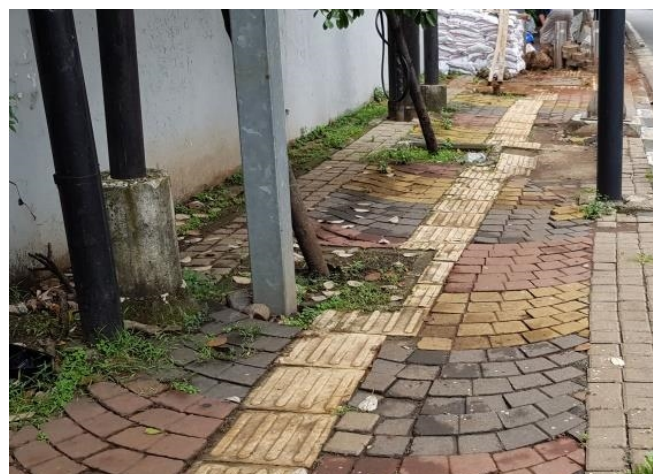

Gambar 29 Tiang listrik, telefon dll yang menghalangi jalan.

Sumber: Dokumentasi penulis, Januari 2018

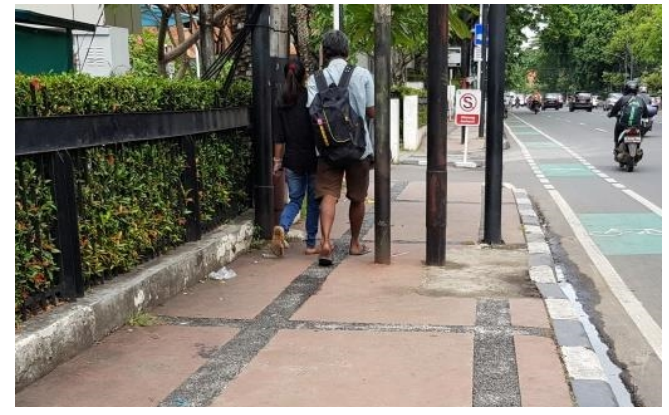

Gambar 30 Tiang listrik, telefon dll yang menghalangi jalan tidak ada jalur tunanetra

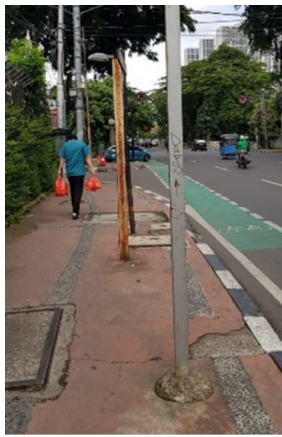

Gambar 31 Tiang listrik, telefon dll yang menghalangi jalan tidak ada jalur tunanetra

Sumber: Dokumentasi penulis, Januari 2018 
Jurnal Planologi Vol. 16, No. 1, April 2019

Available : http://jurnal.unissula.ac.id/index.php/psa

\subsection{Dialog Akademik-Temuan Lapangan}

Pengguna jalur pedestrian di jalan Pangeran Diponegoro mempunyai karakteristik yang bermacam-macam, mulai dari pejalan kaki yang memang hak nya untuk melintasi jalur tersebut, pedagang kaki lima dan pengguna kendaraam bermotor baik yang berhenti untuk parkir maupun yang melintasi jalur pedestrian tersebut. Adanya pelebaran jalur pedestrian di sisi depan RSCM membuat jalur pedestrian tersebut lebih mempunyai karakteristik dan mempunyai penggunaan yang tinggi dibandingkan jalur pedestrian sisi lainnya. Penggunaan jalur pedestrian yang ramai baik dari pejalan kaki sendiri maupun pedagang kaki lima bisa menjadikan bentuk pengawasan dari secara natural atau yang disebut oleh jacob sebagai "eyes on the street". Jalur pedestrian yang baik tidak bergantung pada pengawasan petugas keamanan ataupun kamera pengawas, namun pada pengawasan dari para pelaku pejalan kaki tersebut yang secara tidak sadar saling mengamati oleh orang-orang itu sendiri (Jacob, 1961 dalam LeGates and Stout, 2016:152). Jacobs merekomendasikan sejumlah besar toko, bar, restoran, dan tempat umum lainnya dibangun di jalur pedestrian sebagai bentuk kontrol sesama pengguna jalur pedestrian. Pedagang kaki lima yang berjualan di jalur pedestrian tidak bisa dilihat hanya sebagai pelaku yang menggangu ketertiban umum, akan tetapi fungsi sebagai interaksi sosial dan pengawasan terhadap sesama pengguna jalur pedestrian menjadi lebih utama.

Jane Jacob memberikan alasan mengapa pihak pedagang kaki lima tersebut penting berada pada jalur pedestrian sebagai berikut:

1. Pertama, Pedagang kaki lima tersebut akan menjadi daya tarik bagi penduduk untuk melewati jalur tersebut karena tingkat keramaian atau aktivitasnya.

2. Kedua, Pelaku pedagang kaki lima biasanya akan menjadi pengawas secara tidak langsung dilokasi dia berdagang.

3. Ketiga, dengan adanya aktivitas jual beli, maka akan menjadi daya tarik bagi yang lain untuk melewati jalur tersebut., karena kecenderungan orang untuk melewati jalur yang lebih ramai ketika berjalan kaki sebagai respon terhadap keamanan bagi diri sendiri.

Salah satu alternatif yang bisa diberikan pada pedagang kaki lima adalah dengan memberikan mereka ruang pada jalur pedestrian untuk melakukan aktivitasnya, tetapi dengan adanya batasan ruang yang jelas sehingga jalur pedestrian sebagai fungsi awalnya untuk jalur bagi orang berjalan kaki tetap dapat berjalan sebagaimana mestinya.

Keamanan bagi pengguna jalur pedestrian tidak hanya dari tindakan kejahatan atau kriminalitas yang terjadi di jalan akan tetapi juga dari kendaraan yang terkadang melintasi 
Jurnal Planologi Vol. 16, No. 1, April 2019

di jalur pedestrian. Indonesia sebagai negara berkembang juga mempunyai tingkat kecelakaan bagi pejalan kaki yang cukup tinggi yaitu sebesar $30 \%$ dari total kecelakaan pada tahun 2013. Pada jalur pedestrian di jembatan Sungai Ciliwung sering terjadi pengguna kendaraan bermotor melintasi jalur pedestrian yang membuat kemanan pejalan kaki terganggu. Sedangkan pada jalur pedestrian di depan RSCM kendaraan bermotor yang melintas didominasi oleh pelaku ojek online maupun ojek pangkalan. Le Corbusier (1929, dalam LeGates and Stout, 2016:383) mengatakan bahwa traffic lalu lintas yang tinggi sering membahayakan para pengguna pedestrian bahkan banyak kecelakaan (membunuh) diakibatkan para pengguna kendaraan bermotor di jalan raya. Memang pada praktiknya, kejadian ini terjadi pada saat jalan Pangeran Diponegoro sedang macet terutama pada jam sibuk pulang kerja dan siang. Jika hal ini tidak dilakukan tindakan maka semakin lama akan membuat jalur tersebut berbahaya bagi pengguna jalur pedestrian. Pejalan kaki tidak mendapatkan haknya untuk bisa mengakses jalur pedestrian secara bebas, aman, dan nyaman. Salah satu strategi dalam hal ini adalah dengan memberikan pembatas antara jalan dan jalur pedestrian sehingga kendaraan bermotor tidak bisa masuk ke jalur pedestrian.

Fungsi dasar jalur pedestrian dibuat untuk pergerakan manusia dari satu tempat ke tempat yang lain dengan moda berjalan kaki, dan bisa diakses oleh siapapun baik bagi anak kecil, lansia, ibu hamil, maupun penyandang disabilitas. Suatu jalur pedestrian yang baik tidak hanya dari sisi visual, akan tetapi juga dari aksesiblenya. Pelebaran jalur pedestrian dengan membangun fasilitas untuk berinteraksi sosial seperti tempat duduk akan menciptakan kondisi visual yang baik. Kevin Lynch menentukan elemen pembentuk citra kota yang salah satunya adalah path. Path adalah suatu jalur yang biasanya digunakan orang untuk melakukan pergerakan secara umum. Path dapat berupa jalan raya, jalur pejalan kaki(walk ways), jalur transit, kanal, jalur kereta api dll (Lynch, 1960:41). Bagi kebanyakan orang path merupakan elemen yang paling penting dalam pembentukan kualitas image kota. Sama dengan apa yang diutarakan oleh Jane jacob(1961) bahwa jalan dan pedestriannya merupakan organ vital suatu kota dimana mencerminkan baik atau buruknya suatu kota secara visual.

Adanya jalur pedestrian dengan kondisi yang tidak baik atau banyak kerusakan akan membuat citra dari kawasan tersebut menjadi buruk. Jalur pedestrian pada penggal jalan Pangeran Diponegoro hanya sebagian yang mempunyai citra baik, akan tetapi masih banyak titik dengan kondisi jalur pedestrian yang buruk seperti jalur pedestrian yang tidak rata, rusak, tidak tersedia jalur khusus tunanetra, dan kondisi fisik jalur pedestrian yang 
banyak kerusakan. Hanya pada sisi RSCM sepanjang 600meter dan jalur pedestrian di depan RSCM yang menyatu bersama taman Diponegoro mempunyai kondisi visual yang baik. Untuk itu, perbaikan kondisi fisik pada jalur pedestrian akan bisa memperbaiki kondisi visual dari kawasan secara keseluruhan.

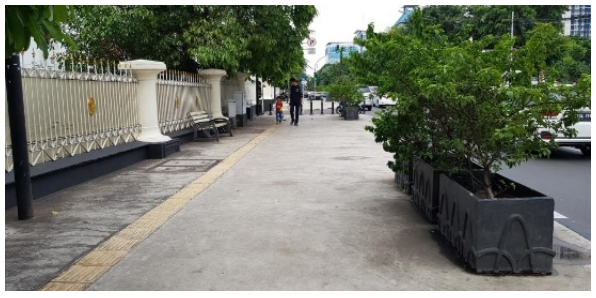

Gambar 32 Kondisi jalur pedestrian depan RSCM mempunyai visual yang baik

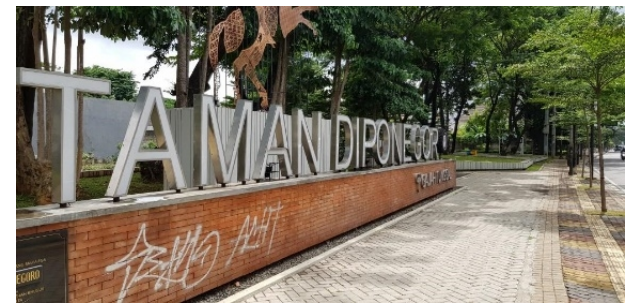

Gambar 33 Kondisi jalur pedestrian yang menyatu dengan taman Diponegoro membuat pandagan visual yang baik.

Sumber: Dokumentasi penulis, Januari 2018

Pada jalur pedestrian penggal jalan Pangeran Diponegoro, ada beberapa sisi jalur yang bisa diakses oleh semua orang tapi ada juga sisi yang tidak semua orang bisa mengakses jalur pedestrian tersebut. Jalur yang bisa diakses oleh semua orang adalah jalur pedestrian didepan RSCM. Jalur tersebut mempunyai fasilitas untuk penyandang disabilitas dan tunanetra. Jalur khusus tunanetra tersedia sepanjang jalur pedestrian tersebut. Akan tetapi pada sisi ujung jalur pedestrian tersebut, jalur khusus tunanetra tidak tersedia, karena jalur tersebut merupakan pintu keluar masuk kendaraan ke jalan raya. Seharusnya jalur pedestrian khusus tunanetra tersebut tetap ada walaupun area tersebut merupakan jalur keluar masuk kendaraan. Bisa juga dengan merubah material jalan menjadi paving blok sehingga jalur khusus tunanetra tetap bisa disediakan. Pada jalur pedestrian sisi depan RSCM (Penggal A), jalur pedestrian tersebut mempunyai jalur khusus untuk tunanetra, akan tetapi jalur khusus tersebut dibuat berbelok-belok dan mendekati sisi jalan. Hal ini akan membuat kesulitan bagi para tunanetra untuk mengakses jalur pedestrian tersebut. Banyaknya hambatan di jalur seperti lubang, tiang listrik, dan tiang lainnya juga menjadikan jalur tersebut sulit untuk dilalui penggunanya. Pada daerah yang penggal B jalan Pangeran Diponegoro, jalur khusus tunanetra tidak tersedia sama sekali. Hal ini akan membuat para penyandang disabilitas tersebut akan kesulitan, padahal pada jalur tersebut ada shalter busway sebagai transporasi umum. 


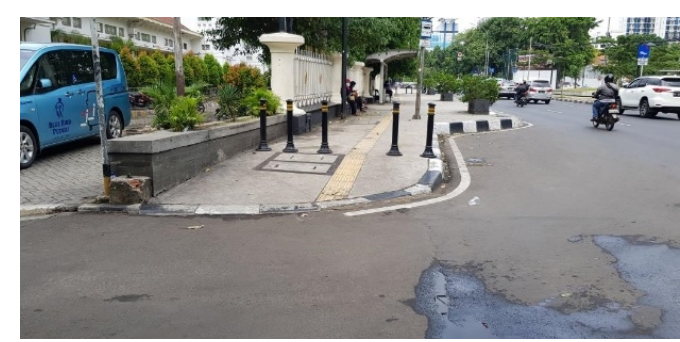

Gambar 34 Jalur khusus tunanetra terputus dan tidak menyambung dengan pedestrian sebelahnya

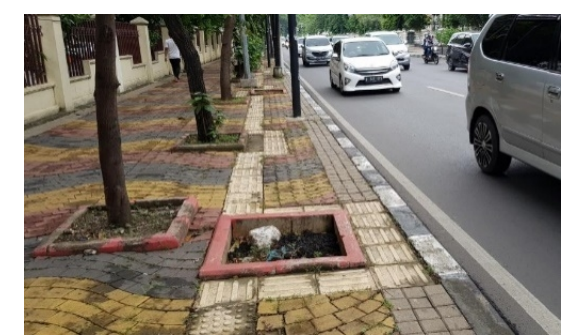

Gambar 35 Jalur khusus tunanetra dibuat berbelok akan menyulitkan para penggunanya. penulis, Januari 2018

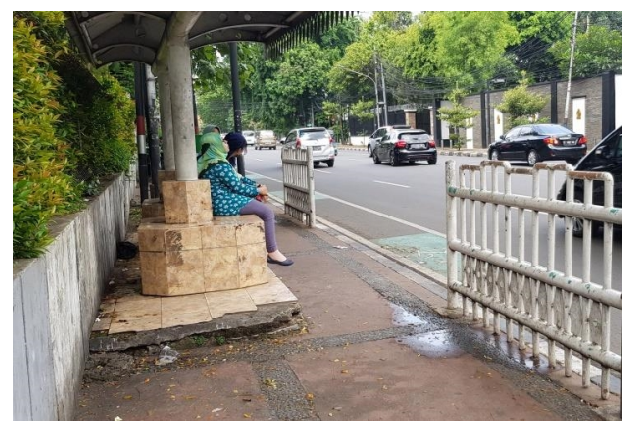

Gambar 36 shalter busway yang tidak mempunyai jalur khusus tunanetra.

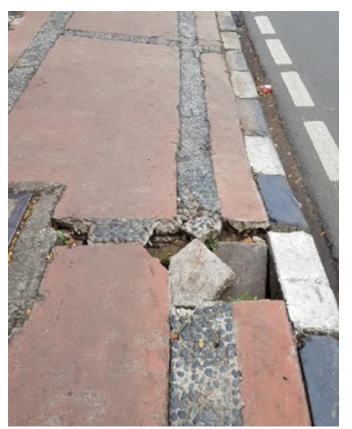

Gambar 37 Jalur pedestrian tidak mempunyai jalur tactile paving dan kondisinya berlubang Sumber: Dokumentasi penulis, Januari 2018

Lynch (1981) menyatakan bahwa salah satu salah satu elemen pembentukan kota adalah akses. Akses disini artinya tingkatan dimana kota memiliki kemudahan pelayanan yang dapat dijangkau oleh masyarakat, kemudahan melakukan aktivitas kota, kemudahan menjangkau sumber daya, kemudahan pelayanan dan pencapaian, kemudahan informasi atau kemudahan menjangkau tempat (Lynch,1981). Kemudahan akses ini harus berlaku bagi semua orang termasuk orang yang memiliki kemampuan berbeda seperti anak kecil, penyandang disabilitas, orang lanjut usia, orang sakit, ibu hamil, dll. (Lynch,1981). Jalur pedestrian sebagai salah satu akses pergerakan bagi penggunanya harus bisa digunakan bagi semua orang termasuk bagi penyandang disabilitas, karena akses sebagai jalur pedestrian harus bisa memberikan hak yang sama bagi para pejalan kaki.

\section{KESIMPULAN DAN SARAN \\ 4.1 Kesimpulan}

Hakikatnya jalur pedestrian dibuat untuk pergerakan manusia dari satu tempat ke tempat yang lain dengan moda berjalan kaki, dan bisa diakses oleh siapapun baik bagi anak kecil, lansia, ibu hamil, maupun penyandang disabilitas. Pedestrian juga harus bisa diakses oleh semua orang dengan aman dan nyaman. Penggunaan jalur pedestrian di penggal jalan 
Jurnal Planologi Vol. 16, No. 1, April 2019

Pangeran Diponegoro mempunyai intensitas yang tinggi dibandingkan dengan jalur pedestrian pada sisi lain. Tingginya intensitas penggunaan tersebut didukung dengan pedagang kaki lima yang berjualan dapat memberikan pengawasan secara tidak langsung pada sesama pengguna jalur pedestrian, dan menjadikan daya tarik orang untuk lebih memilih jalur tersebut ketika melakukan jalan kaki.

Adanya kendaraan bermotor yang melintas dan parkir di jalur pedestrian dapat membahayakan dan menjadi penghambat bagi pengguna pejalan kaki. Faktor keamanan dari sisi kendaraaan bermotor masih belum bisa dihindari karena bentuk jalur pedestrian yang masih bisa secara paksa dilewati oleh penguna kendaraan bermotor untuk melintas. Untuk itu, diperlukan modifikasi desain agar para pengguna kendaraan bermotor tidak lagi menggunakan jalur pedestrian baik untuk melintas ataupun untuk parkir.

Hanya bagian penggal jalan depan RSCM jalur pedestrian bisa diakses oleh semua orang dikarenakan mempunyai kondisi fisik yang paling baik diantara jalur pedestrian sisi lainnya. Akan tetapi bagi para penyandang tunanetra juga akan sedikit kesulitan ketika terjadi perpindahan sisi jalur pedestrian dikarenakan jalur khusus tunanetra tersebut masih belum tersambung ke semua pedestrian. Berdasarkan hal diatas, jalur pedestrian di jalan Pangeran Diponegoro bisa diakses secara aman dan nyaman hanya pada penggal jalan depan RSCM dikarenakan kondisi jalur pedestrian yang lebar, mempunyai ruang untuk interaksi sosial, dan dilengkapi dengan jalur khusus penyandang disabilitas.

\subsection{Saran}

Jalur pejalan kaki sebagai salah satu fasilitas publik harus bisa diakses oleh semua orang baik anak-anak, wanita, pria, orang tua, maupun orang-orang berkebutuhan khusus. Jalur pedestrian ini sangat penting terutama yang berada di kawasan mixed use. Saat ini Kota Jakarta sudah mulai mengembangkan jalur pedestrian yang bisa diiakses oleh semua pengguna pejalan kaki. Akan tetapi masih belum menjangkau semua tempat atau jalan, masih banyak jalur pejalan kaki yang sulit diakses bagi penyandang disabilitas. Pemerintah Kota khususnya harus menjadikan jalur pedestrian ini sebagai fokus utama dalam mengembangkan jalur transportasi massal. Hal ini dikarenakan jalur pejalan kaki adalah akses penghubung antar moda transportasi umum. Jika jalur pejalan kaki tidak memadai, akan sulit mengembangkan atau memindahkan orang untuk bisa mengakses ke transportasi massal. 
Jurnal Planologi Vol. 16, No. 1, April 2019

Available : http://jurnal.unissula.ac.id/index.php/psa

\section{PERNYATAN RESMI}

Semua Penelitian ini didanai berdasarkan Beasiswa-Saintek Kemenristekdikti Program Gelar Tahun 2017.

\section{DAFTAR PUSTAKA}

INRIX Global Traffic Scorecard INRIX Research Graham Cookson \& Bob Pishue February 2017

Jacobs, Jane. (1961). Chapter 2 : The Use Of Sidewalks : Safety. The Death and Life of Great American City. New York : Vintage.

LeGates, RT, \& Stout, F. (2016). The City Readers Sixth Edition. Routledge Press: London.

Lynch, Kevin, (1981). A Theory of Good City Form. The M.I.T. Press. Cambridge, Massachusetts.

Lynch, Kevin. (1960), The Image Of The City, The MIT Press, Cambridge, Massachusetts. Pemerintah Indonesia. (2009). Undang-Undang No. 2 Tahun 2009 tentang Lalu Lintas dan Angkutan Jalan. Lembaran RI Tahun 2009, No. 2. Jakarta: Sekretariat Negara.

World Health Organization (2013). Pedestrian safety: a road safety manual for decisionmakers and practitioners. Geneva: World Health Organization (WHO)

Yunus, H. S. (2012). Metode Penelitian Wilayah Kontemporer. Yogyakarta: Pustaka Pelajar

http://industri.bisnis.com/read/20140919/98/258593/angka-kecelakaan-pejalan-kakisumbang-30-korban-laka-lantas diakses pada 27 Januari 2018

http://www.viva.co.id/berita/metro/795744-pemprov-dki-bakal-perlebar-trotoar-hingga-14meter diakses pada 27 Januari 2018 